\title{
Comparative Evaluation of Mekonen Beehive Technology with Zander and KTB Beehive Types on Honey Yield and Cost Benefit Analysis Under Sidama Condition, Ethiopia
}

\author{
Dinku Negash*, Mekonen Debara, Bangu Bekel, Amare Aregaw \\ South Agricultural Research Institute, Hawassa Research Center, Hawassa, Ethiopia \\ Email address: \\ negash.dinku@yahoo.com (D. Negash) \\ ${ }^{*}$ Corresponding author \\ To cite this article: \\ Dinku Negash, Mekonen Debara, Bangu Bekel, Amare Aregaw. Comparative Evaluation of Mekonen Beehive Technology with Zander and \\ KTB Beehive Types on Honey Yield and Cost Benefit Analysis Under Sidama Condition, Ethiopia. International Journal of Biomedical \\ Materials Research. Vol. 8, No. 2, 2020, pp. 29-33. doi: 10.11648/j.ijbmr.20200802.14
}

Received: October 20, 2020; Accepted: December 9, 2020; Published: December 22, 2020

\begin{abstract}
Hive is essential for honey bees to build their nests in such a way that it is easy to manage and maintain them. This study examined three beehive types: namely Mekonen, Zander model and Kenya Top Bar Hive (KTB), based on honey yield performance and profitability under Sidama condtion, Ethiopia. A total of 9 honeybee colonies which had similar strength were selected for comparison of different beehive in Remeda and Dilla substation. Honey yield data from each hive per harvesting season was recorded immediately after harvest. The overall average annual honey yield performance clearly revealed that Mekonen hive $(26.77 \pm 3.25 \mathrm{~kg} / \mathrm{hive})$ were significantly higher $(\mathrm{p}<0.05)$ than zander hive $(20.77 \pm 2.33 \mathrm{~kg} / \mathrm{hive})$ and KTB hive $(17.61 \pm 4.20 \mathrm{~kg} /$ hive $)$. While, in both sub research station there was no significant difference in honey yield among the three hives. Mekonen hive stands first due to honey yield and preference while, KTB hive was affordable to the farmers due to cost and durability of the frame and ventilation followed by improved frame hive compared to Mekonen hive. It is therefore recommended to use the Mekonen hive as an alternative technology in addition to KTB and frame hive.
\end{abstract}

Keywords: Bee Hives Type, Honey Yield, Production Cost

\section{Introduction}

The presence of diverse agro-climatic zones resulted from the diverse topographic variations make the country suitable for many bee floras. This situation plays role for the large number of honeybee colonies present in Ethiopia. The sole purpose of a hive is to encourage the bees to build their nests in such a way that it is easy to manage and maintain them [5, 10]. Ethiopia has long tradition with most of the colonies nested under traditional hives. To improve the livelihoods of rural people in Ethiopia, several beekeeping development projects over the last 50 years have introduced different designed equipment to actively manage their colonies and increase honey production. In recent years, Kenya Top Bar Hive (KTB) and improved frame hives are in the country introduced to the beekeepers in the study area though the rate of adoption is very low [9].

In addition to these, Mekonen hive model was innovated by Hawassa Agricultural research center. It is a circular structure which is designed by Mr. Simamelak Mokonen for local honey bee eco-type. It is enclosed made of wooden materials and it's have 30 circular frames, three open doors, queen excluder and best suited for local honey bee type for honey production. The designed hive is horizontal and circular position for local eco-type bees similar with traditional bee hive. High yield of honey, ease of inspection to know the status of colony and ease of product harvesting are the major advantage of modern and KTB hives over traditional ones. Improved frame hives enhance honey production because they save bees' effort in creating beeswax comb: for that reason, improved frame hives enable harvests of honey rather than beeswax [6]. However, the colony strength and hive preference of honeybees varied in different environmental conditions and different honeybee races [1].

So far, there is no study undertaken to assess the performances of colonies in different beehives and their 
profitability under the environmental conditions of the study areas. In order to improve beekeeping sector, selection and adoption of hive types has to be based on productivity, affordability, availability and profitability. Thus, the purposes of this study were to identify suitable beehive to honeybees, to evaluate yield performance and profitability of beehive types at Sidama and Gedeozone condition

\section{Materials and Methods}

\subsection{Study Area}

The study was conducted at Hawassa Agricultural Research Center (HARC), Sidama Region, during 2016 and 2018. Elevation of the area ranges from 1500 to 3500 m.a.s.l. and mean annual rainfall varies between $1200 \mathrm{~mm}$ to $1999 \mathrm{~mm}$ with $15^{\circ} \mathrm{C}$ to $19.9^{\circ} \mathrm{C}$ mean annual temperature. The main crops cultivated in the study area is coffee, Enset, Barley, Wheat, Maize, Chickpea, Bean, Pea, Lentil and Haricot bean. The major livestock raised in the zones are cattle, donkey, goats, sheep, mules, and chicken and honeybee colonies [11].

\subsection{Experimental Treatments and Data Collection}

Three beehive types namely: improved frame hive (Zander model), Kenya Top Bar hive (KTB) and Mekonen bee hives were used as treatments. Each beehive type was replicated three times. All hives types were purchased from Hawassa bee hives technology dealer. Three strong and well-established honeybee colonies from each hive type were selected and kept under uniform environmental condition. Equal honeybee management practice was undertaken to each beehive type.

During the study period the data was collected on honey yield and production cost of each beehive types. Data on honey productivity (yield performance) of each of three beehive types were recorded. Hence, total cost of production was calculated for consecutive years of honey flow seasons. Finally, selling price for a $\mathrm{kg}$ of honey in local market was assessed in the study areas. Assuming that, an average beekeeper will have 5 bee hives in the apiary, cost benefit analysis of each beehive types was determined using the following formula $[7,8]$.

$$
\mathrm{NI}=\mathrm{GR}-\mathrm{TC},
$$

$\mathrm{NI}=$ Net Income, GR $=$ Gross Return, $\mathrm{TC}=$ Total production Cost

\subsection{Data Analysis}

The data was analyzed using SPSS software programs version 23. Every comparison was made assuming variation between the beehive types in honey productivity. Two-way ANOVA were computed to compare honey productivity means per annum by using GLM and Tukey's honest significant difference (HSD) at 5\% level of significance was used for mean separation whenever significant results encountered between beehive types.

\section{Result and Discussion}

\subsection{Honey Yield Performance of Beehive Types}

The highest average honey yield per hive was recorded from Mekonen $(26.77 \pm 3.25 \mathrm{~kg})$ than Zander hive $(20.77 \pm 2.23 \mathrm{~kg})$ and $17.61 \pm 4.20$ kilogram of honey from KTB hive were harvested. The present study revealed that there was no significant difference in honey production per hive between Zander and KTB ( $>>0.05)$. However, Mekonen hive showed significantly high average production of honey from other hives $(p<0.05)$ (Table 1$)$. The productivity of Mekonen hive in this study is more than that of Zander hive and KTB hive, which might be due to suited to establish their colonies earlier, similarity of the hive with traditional hive for local honey bee it's known before practiced and maintain optimum hive temperature during hot and cold season than other hive types. The difference in honey yield between KTB hive with Mekonen and Zander hive might be due to the difference in the time of honey bees spent for building comb in the Kenyan top bar hive. In the present study, lower honey yield was obtained from Zander hive and higher honey yield from KTB than Bonga area. which indicate that average annual honey yield of KTB and Zander hives at south west Ethiopia level was reported $15.71 \pm 2.22 \mathrm{~kg}$ (crude honey/hive) and 30.09 \pm 2.69 $\mathrm{kg} /$ hive, respectively $[4,3]$. while, the average annual honey yield of zander hive was (21.02 kg/hive) in mid Rift Valley of Ethiopia and average honey yield per year/colony was $22 \pm$ 4.56 kilogram from Zander hive and 16.2 \pm 4.12 from KTB [2, $10,12,13]$ in Jimma and Gonder Zone respectively.

Where;

Table 1. Honey Productivity of Different Hive Ty pes.

\begin{tabular}{llll}
\hline \multirow{2}{*}{ Type of hives } & \multirow{2}{*}{ Mean \pm SD } & $\mathbf{9 5 \%}$ Confidence Interval & Upper Bound \\
\cline { 3 - 4 } & & Lower Bound & 28.439 \\
\hline Mekonen & $26.77 \pm 3.25 \mathrm{~b}$ & 25.117 & 22.439 \\
Zander & $20.77 \pm 2.23 \mathrm{a}$ & 19.117 & 19.272 \\
KTB & $17.61 \pm 4.20 \mathrm{a}$ & 15.950 & \\
\hline
\end{tabular}

The result of variance analysis showed that hive type had significant effect on honey yield per hive (Table 2). There was a statistically significant main effect for hive type $[\mathrm{F}(2,36)=40.29$, $\mathrm{p}=0.000]$; however, the main effect for year $[\mathrm{F}(2,36)=0.885$, $\mathrm{p}=0.422]$, location $[\mathrm{F}(1,36)=0.007, \mathrm{p}=0.934]$ and the interaction effect $[\mathrm{F}(4,36)=0.025, \mathrm{p}=0.999]$ did not reach statistical significance (Table 2).

Although location and harvesting year had no significant effect on honey yield/ hive $p>0.05$ (Table 2), this is might be the existence of similar bee forage, management practice and 
environmental condition of the study research station. This finding differ with results suggested by also indicated that as there is a variation in the seasonal availability of honeybee forages in different agro-ecology resulted in different for honey yield of Tigray region.

Table 2. Tests of Between-Subjects Effects.

\begin{tabular}{lllll}
\hline Source & Sum of Squares & df & Mean Square & F \\
\hline Intercept & 24066.667 & 1 & 24066.667 & 2268 \\
location & 0.074 & 1 & 0.074 & 0.000 \\
Type of hive & 855.111 & 2 & 427.556 & 0.934 \\
year & 18.778 & 2 & 9.389 & 40.293 \\
location * type of hive & 4.148 & 2 & 2.074 & 0.885 \\
location * year & 2.704 & 2 & 1.352 & 0.195 \\
Type of hive * year & 125.444 & 4 & 31.361 & 0.127 \\
location * type of hive * year & 1.074 & 4 & 0.269 & 2.955 \\
Error & 382 & 36 & 10.611 & 0.422 \\
Total & 25456 & 54 & & 0.823 \\
\hline
\end{tabular}

The present study revealed that honey yield is not different in three harvesting year of Mekonen and zander hive $(p>0.05)$. But, there is a significant interaction effect on honey yield of KTB hive in different harvesting year. Honey yield from 2017 is higher than 2016 and 2018 harvesting season of all hive types. Honey yield achieved relatively better performance in 2017 year. This might be due to availability of ample bee forage and suitable climatic conditions for honeybees to provide high honey yield in 2017 harvesting year of all hive types.

Table 3. Effect of Year and Hive Type on Honey Yield.

\begin{tabular}{|c|c|c|c|c|c|}
\hline \multirow{2}{*}{\multicolumn{2}{|c|}{ Type of hives Year }} & \multirow{2}{*}{ Mean } & \multirow{2}{*}{ Std. Error } & \multicolumn{2}{|c|}{ 95\% Confidence Interval } \\
\hline & & & & Lower Bound & Upper Bound \\
\hline \multirow{3}{*}{ Mekonen } & 2016 & $26.0 \mathrm{a}$ & 1.419 & 23.123 & 28.877 \\
\hline & 2017 & $28.0 \mathrm{a}$ & 1.419 & 25.11 & 30.877 \\
\hline & 2018 & $26.3 \mathrm{a}$ & 1.419 & 23.456 & 29.210 \\
\hline \multirow{3}{*}{ Zander } & 2016 & $19.5 \mathrm{a}$ & 1.419 & 16.623 & 22.377 \\
\hline & 2017 & $22.0 \mathrm{a}$ & 1.419 & 19.123 & 24.877 \\
\hline & 2018 & $20.8 \mathrm{a}$ & 1.419 & 17.956 & 23.710 \\
\hline \multirow[t]{2}{*}{ KTB } & 2017 & $20.0 \mathrm{~b}$ & 1.419 & 17.523 & 22.877 \\
\hline & 2018 & $16.5 \mathrm{a}$ & 1.419 & 13.623 & 17.377 \\
\hline
\end{tabular}

A statistical analysis was run to determine differences in honey yield between hive types. Significant differences $(\mathrm{p}<$ 0.05 ) were observed in the results presented below; all hive types are statistically significantly different from one another. That is, Mekonen, Zander and KTB bee hives differ significantly in terms of their honey production. This variation might be due to the larger comb size and thickness of Mekonen combs than the other hives. This result also indicates that if all frames in Mekonen hive are filled with ripened honey at good times, the production potential of
Mekonen would exceed much higher than modern and KTB hives under such ideal conditions. On farm evaluation of the productivity of KTB and modern hives in Begasheka and Debrekidan districts of Tigray regional state indicated that KTB provided average honey yield of $17.82 \mathrm{~kg} /$ hive while modern hive provided $22.80 \mathrm{~kg} /$ hive of average honey yield. Such variations indicate that local environmental factors particularly of climate and bee flora availability and hive preference have impact on honey yield of the different hives.

Table 4. Multiple Comparisons for Honey Yield for Hive Type Interaction Turkey HSD.

\begin{tabular}{|c|c|c|c|c|c|c|}
\hline \multirow{2}{*}{$\mathbf{X}$} & \multirow{2}{*}{$\mathbf{Y}$} & \multirow{2}{*}{ Mean Difference } & \multirow{2}{*}{ Std. Error } & \multirow{2}{*}{ Sig. } & \multicolumn{2}{|c|}{$5 \%$ Confidence Interval } \\
\hline & & & & & Lower Bound & Upper Bound \\
\hline \multirow{2}{*}{ Mekonen } & Zander & $6.4444^{*}$ & 1.085 & 0.000 & 3.790 & 9.098 \\
\hline & KTB & $9.5556^{*}$ & 1.085 & 0.000 & 6.901 & 12.209 \\
\hline \multirow{2}{*}{ Zander } & Mekonen & $-6.4444 *$ & 1.085 & 0.000 & -9.098 & -3.790 \\
\hline & KTB & $3.1111^{*}$ & 1.085 & 0.019 & 0.457 & 5.765 \\
\hline \multirow{2}{*}{ KTB } & Mekonen & $-9.5556^{*}$ & 1.085 & 0.000 & -12.20 & -6.901 \\
\hline & Zander & $-3.1111^{*}$ & 1.085 & 0.019 & -5.765 & -0.457 \\
\hline
\end{tabular}

The error term is Mean Square (Error) $=10.611$. $*$ The mean difference is significant at the 0.05 level.

\subsection{Cost and Return Analysis of Beehive Types}

Gross return of Mekonen hive was stands first when compared to other beehive types (Tables $5 \& 6$ ). However, total cost of production for KTB hive was much cheaper than Mekonen and zander hive (See table 5). Significant amount of money can be earned from selling of pure honey produced per Mekonen hive than from zander hive. This indicated that 
13038 ETB from Mekonen hive, 12450 ETB from KTB and 12450 ETB from Zander hive afford net income per beekeeper from 5 hives. The study clearly showed that
Mekonen and KTB hive were the better income generation per beekeeper from selling of honey.

Table 5. Presentation of Production Costs of Each Beehive Types.

\begin{tabular}{|c|c|c|c|c|c|c|}
\hline Major items & Unit price (ETB) & Service year of items & Items per beekeeper & Mekonen & Zander & KTB \\
\hline Casting mould & 5000 & 10 & 1 & 500 & 500 & \\
\hline Honey extractor & 5000 & 10 & 1 & 500 & 500 & \\
\hline Beeswax (kg) & 300 & 2 & 10 & 2000 & 2000 & \\
\hline Overall & 1000 & 5 & 1 & 1000 & 1000 & 1000 \\
\hline Glove & 100 & 1 & 2 & 200 & 200 & 200 \\
\hline Mekonenn & 1500 & 10 & 5 & 1500 & & \\
\hline KTB & 900 & 10 & 5 & & & 900 \\
\hline Shelter & 3000 & 5 & 1 & 1000 & 1000 & 1000 \\
\hline Smoker & 200 & 4 & 1 & 400 & 400 & 400 \\
\hline Battery & 100 & 2 & 1 & 100 & 100 & 100 \\
\hline Feeding & 200 & & 5 & 200 & 200 & 200 \\
\hline Hive stand & 200 & 10 & 5 & 200 & 200 & 200 \\
\hline Total production cost & & & & 7850 & 8150 & 4350 \\
\hline
\end{tabular}

Table 6. Yearly Cost and Return of Each Beehive Types Per Beekeeper Owned 5 Bee Hives.

\begin{tabular}{|c|c|c|c|c|}
\hline Beehive type & Total production cost (ETB) & Gross return (ETB) & Net income per beekeeper (ETB) & Net income per hive (ETB) \\
\hline Mekonenn & 7850 & 20888 & 13038 & 2607.6 \\
\hline Zander & 8150 & 16000 & 7850 & 1570 \\
\hline KTB & 4350 & 16800 & 12450 & 2490 \\
\hline
\end{tabular}

Table 7. Characteristic View After 3 Years of Keeping Different Types of Beehives.

\begin{tabular}{|c|c|c|c|c|}
\hline Characteristic & MH & Zander & KTB & NOTES \\
\hline $\begin{array}{l}\text { Hive } \\
\text { management }\end{array}$ & $* *$ & $* * * *$ & $* *$ & $\begin{array}{l}\text { KB hives require more time to manage due to frameless combs. Great difficulty was encountered in } \\
\text { the inspection of established Mekonenn hives. The combs were not easily removable, because the built } \\
\text { combs were firmly glued to frames and hives wall. Attempt to remove the combs would lead to } \\
\text { destruction of the combs. If swarm season coincide with a busy month at work, I can just slap on a few } \\
\text { Frame hive to give my co workers more. In a } \mathrm{KBH} \text { and } \mathrm{MH} \text {, we don't have this comfort. }\end{array}$ \\
\hline Ventilation & * & $* *$ & $* * *$ & $\mathrm{MH}$ make worse to emit heat and moisture to rise up and out of the hive rather than KTB and Zander \\
\hline Cost & $* *$ & $* *$ & $* * * *$ & $\begin{array}{l}\text { MH and Zander hives set-up for one hive will cost about } 1500 \text {-2000 birr, plus another } 6000 \text { birr for } \\
\text { additional equipments }\end{array}$ \\
\hline Harvesting honey & $* *$ & $* * * *$ & $* *$ & $\begin{array}{l}\text { Crushing honey comb by hand from a } \mathrm{KBH} \text { and } \mathrm{MH} \text {, while ease of harvesting honey from a Zander } \\
\text { hive is using a extractor }\end{array}$ \\
\hline Frame durability & $* *$ & $* * * *$ & $* * * *$ & $\begin{array}{l}\text { In terms of durability, only the MH hive frame had short life span. It is more or less a seasonal hive } \\
\text { type that cannot survive the forces of rain, bush fire and human or animal activities. } \\
\text { Once you are done harvesting honey, the frame can't returns into position and unfeasible }\end{array}$ \\
\hline Preference & $* * * *$ & $* * *$ & $* * *$ & $\begin{array}{l}\text { The performance by the best was an indication that bees show preference for } \mathrm{MH} \text { and this may } \\
\text { account for why it is similar with traditional hive its known befor }\end{array}$ \\
\hline Yield & $* * * *$ & $* * *$ & $* *$ & $\begin{array}{l}\text { Amount of honey production from } \mathrm{MH} \text { was better than the others, due to the preference and rapid } \\
\text { colony establishment rate }\end{array}$ \\
\hline
\end{tabular}

**** The more stars $=$ the better, $\mathrm{MH}=$ Mekonen hive and $\mathrm{KTB}=$ Kenya top bar

\section{Conclusion and Recommendation}

Overall, we concluded that the Mekonen hive had better performance in terms of honey yield compared to the Kenyan top bar hive and zander hive. In Dilla station the Kenyan top bar hive and the frame hive had similar honey yields. While, in Remeda station the Mekonen hive had higher honey yield than the Kenyan top bar hive and frame hive. Season of honey harvesting had no effect on honey yield per hives. Hence, Mekonen hive stands first due to honey yield and preference while, KTB hive was affordable to the farmers due to cost and durability of the frame and ventilation followed by improved frame hive compared to Mekonen hive. It is therefore recommended to use the Mekonen hive as an alternative technology in addition to KTB and frame hive.

\section{References}

[1] Abou-Shaara, H. F., A. A. Al-Ghamdi, and A. A. Mohamed. 2013. Honey bee colonies performance enhance by newly modified beehives. J. Apicult. Sci. 57: 45-57. 
[2] Addis Getu and Maleda Birhane. 2014. Chemical analysis of honey and major honey production challenges in and around Gonder, Ethiopia. Aca. J. Nut. 3 (1)'.

[3] Atsbaha Hailemariam, Taye Tolemariam and Kebede Debele. 2015. Assessment of honey production system, constraints and opportunities in three selected Woredas of Tigray, Basic Research Journal, 4: 304-315.

[4] Awraris Getachew, Amenay Assefa, Hailemariam Gizaw, Nuru Adgaba, Dejen Assefa, Zerihun Tajebe and Asrat Tera. 2015. Comparative Analysis of Colony Performance and Profit from Different Beehive Types in Southwest Ethiopia, Global Journal of Animal Scientific Research 3 (1): 178-185.

[5] Beyene, T., D. Abi, G. Chalchissa and M. Wolda Tsadik. 2015. Evaluation of Transitional and Modern Hives for Honey Production in Mid RiftValley of Ethiopia. Global Journal of Animal Scientific Research. 3 (1): 48-56.

[6] FAO. 2012. Beekeeping and sustainable livelihoods: Diversification booklet no. 1. Rome, Italy.

[7] Folayan, J. A., and J. O. Bifarin. 2013. Profitability analysis of honey production in Edo North.
[8] Local Government Area of Edo State, Nigeria. J. Agr. Econ. Dev. 2: 60-64.

[9] Gidey Y, Bethelhem K, Dawit K and Alem M 2012 Assessment of beekeeping practices in Asgede Tsimbladistrict, Northern Ethiopia: Absconding, bee forage and bee pests. African Journal of Agricultural Research Vol. 7 (1), pp. 1-5. DOI: 10.5897/AJAR10.1071. ISSN 1991-637X.

[10] Haftom Gebremedhn and Awet Estifanos. 2013. on farm evaluation of Kenyan Top bar hive (KTBH) for honey Production in Tigray Region, Northern Ethiopia. Livest. Res. Rural Dev. 25.

[11] Gidey Yirga and Kibrom Ftwi. 2010. Beekeeping for rural development: its potentiality and constraints in Eastern Tigray, Northern Ethiopia. Agri J, 5: 201-204.

[12] MoARD. 2017. Livestock Development Master Plan Study. Phase I Report - Data Collection and Analysis, Volume N Apiculture. Addis Ababa, Ethiopia.

[13] Wolaye Kiros and Teklberhan Tsegay. 2017. Honey-bee production practices and hive technology preferences in Jimma and Illubabor Zone of Oromiya Regional State, Ethiopia. 9: 31-43. 